\section{PUMPing plants}

SIR - Flowering and fruit ripening are triggered by a burst of respiration and heat production possibly related to a mitochondrial, cyanide-resistant, uncoupled electron transport pathway ${ }^{1}$. In mammals, transient thermogenesis is linked to a mitochondrial uncoupling protein ${ }^{2}$ (UcP), believed to be a late evolutionary acquisition $^{3}$. A detailed analysis of respiratory control of plant mitochondria led us to propose the existence of an UcP-like factor in plants.

Addition of ATP to potato mitochondria produced a $52 \%$ decrease in the rate of state- 4 respiration and an increase of about $15 \mathrm{mV}$ in the value of the membrane potential $(\Delta \Psi)$ (Fig. 1a). The ATPinduced changes in respiration rate and $\Delta \Psi$, compatible with increased mitochondrial coupling, were unaffected by
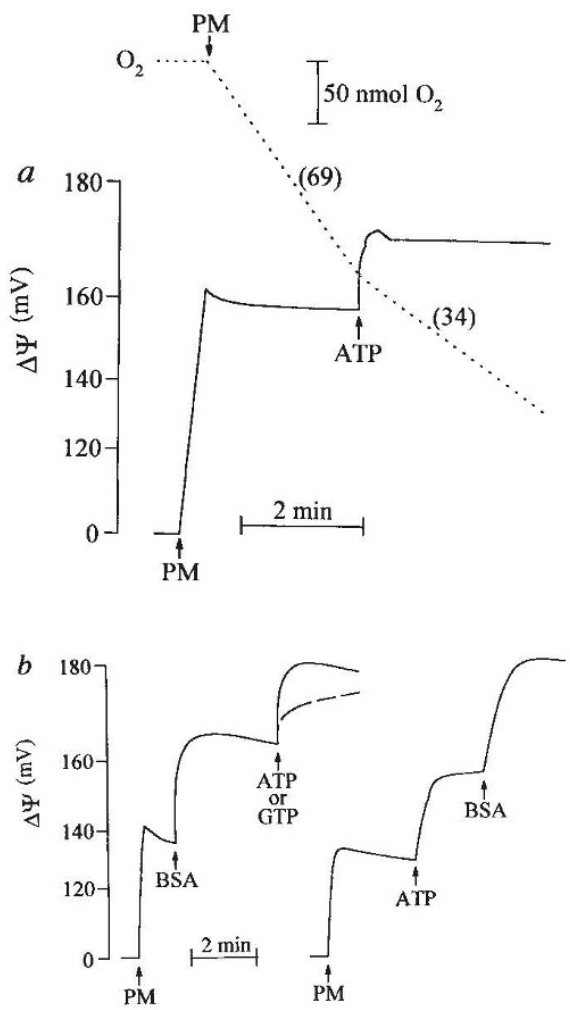

FIG. 1 Effect of ATP, GTP and BSA on transmembrane potential and resting respiratory rate of potato tuber mitochondria (PM). a. PM (1 mg protein $\mathrm{ml}^{-1}$ ) were added to a solution of $300 \mathrm{mM}$ mannitol, $20 \mathrm{mM} \mathrm{KCl}, 10 \mathrm{mM}$ HEPES buffer $\mathrm{pH}$ 7.2, $3 \mathrm{mM}$ tetraphenylphosphonium $\left(\mathrm{TPP}^{+}\right), 5$ $\mathrm{mM}$ succinate and $0.1 \%$ BSA. ATP $(0.1 \mathrm{mM})$ was added as indicated. The numbers in parentheses are rates of oxygen uptake in nmol per min per $\mathrm{mg}$ protein. Oxygen was measured with a Clark electrode in a 1.0-ml magnetically stirred glass chamber. Membrane potential was estimated by measuring extramitochondrial $\mathrm{TPP}^{+}$as described by Kamo et $a l^{7} . b$, PM, isolated in the absence of BSA, were incubated in a medium similar to that in a, lacking BSA. BSA (Sigma, fatty acid free) (1\%), $0.1 \mathrm{mM}$ ATP or GTP were added as indicated. Results are representative of 5 separate experiments. oligomycin $\quad\left(2 \mu \mathrm{g} \mathrm{ml}^{-1}\right)$ or carboxyatractyloside (20mM) (not shown). The membrane potential of potato mitochondria, isolated and incubated without bovine serum albumin (BSA), increased additively by additions of BSA and ATP (Fig. 1b), whereas GTP caused a smaller but significant increase (Fig. $1 b$, dashed line). These results suggested the presence of an $\mathrm{H}^{+}$conductance in potato mitochondria similar to that produced by UcP.

We isolated a protein of relative molecular mass $32,000(32 \mathrm{~K})$ from potato mitochondria and purified it following a procedure used to prepare UcP. We call this protein plant uncoupling mitochondrial protein (PUMP). A common property of the mitochondrial $\mathrm{P}_{\mathrm{i}}$ carrier, the ATP/ADP translocator and $\mathrm{UcP}$ is that these proteins are not retained by hydroxylapatite and at room temperature only $\mathrm{UcP}$ is obtained. Polyacrylamide gel electrophoresis revealed the presence of a $32 \mathrm{~K}$ band both in the brown fat and in plant mitochondrial isolates (Fig. 2, inset).

We incorporated PUMP and UcP into egg phosphatidylcholine liposomes and compared the $\mathrm{H}^{+} / \mathrm{OH}^{-}$transport properties (Fig. 2). The fast alkalinization (Fig. 2, line $a$ ) following valinomycin addition indicates increased $\mathrm{H}^{+} / \mathrm{OH}^{-}$conductance through the incorporated proteins, as it was not observed in protein-free liposomes (Fig. $2 A$, line $b$ ). Figure $2 B$ (line $b$ ) shows the inhibitory potency of externally added GTP to UcP-containing proteoliposomes. The specific activity of $\mathrm{UcP}$ was 7.2 $\pm 1.4 \mu \mathrm{mol} \mathrm{H}{ }^{+}$per min per $\mathrm{mg}(n=5)$ at $28{ }^{\circ} \mathrm{C}$, well within published data ${ }^{5}$. The specific activity of PUMP, determined under similar conditions, was $7.7 \pm 1.5$ $\mu \mathrm{mol} \mathrm{H}{ }^{+}$per min per $\mathrm{mg}(n=5)$. As found previously ${ }^{5}$, addition of $0.1 \mathrm{mM}$ ATP inhibited $50 \%$ of the activity of UcP, whereas $0.05 \mathrm{mM}$ GTP inhibited $80 \%$.

1. Douce, R. \& Neuburger, M. A. Rev. PI. Physiol. Pl. molec. Biol. 40, 371-414 (1989).

2. Nicholls, D. G. \& Locke, R. M. Physiol. Rev. 64, 1-64 (1984).

3. Klingenberg, M. Trends biochem. Sci. 15, 108-112 (1990)

4. Beavis, A. D. \& Vercesi, A. E. J. biol. Chem. 267, 3079-3097 (1992)

5. Winkler, E. \& Klingenberg, M. Eur. J. Biochem. 207, 135-45 (1992).

6. Dizengremel, P. \& Lance, C. PI. Physiol. 58, 147-151 (1976).

7. Kamo, N., Muratsugu, M., Ruji, H. \& Kobatake, J. J. Membrane Biol. 49, 105-121 (1979).
Inhibitions of PUMP activity by $0.1 \mathrm{mM}$ ATP or $0.05 \mathrm{mM}$ GTP were $50 \%$ and $35 \%$, respectively, showing that the nucleotides inhibited PUMP less than UcP. The inhibition by ATP and GTP in the reconstituted system is compatible with their observed effect in intact mitochondria (Fig. 1). Although at present we have isolated PUMP only from potato tubers, we have observed (not shown) that mitochondria of other plants show the type of respiratory control (Fig. 1) that led us to detect PUMP. As potato mitochondria do not present cyanide-resistant respiration ${ }^{6}$, PUMP may be important in this tuber for heat-requiring physiological events.

\section{Anibal E. Vercesi}

lone S. Martins

Marco Aurelio P. Silva

Helena Maria F. Leite

Departamento de Bioquímica,

Instituto de Biologia,

Universidade Estadual de Campinas, 13084-100 Campinas, São Paulo, Brazil

Iolanda Midea Cuccovia

Hernan Chaimovich

Departamento de Bioquímica,

Instituto de Química,

Universidade de São Paulo,

05508-900 São Paulo, Brazil 